\title{
SOUND SOURCE INFLUENCE TO THE ROOM ACOUSTICS QUALITY MEASUREMENT
}

\author{
Siniša Fajt, Miljenko Krhen, Marin Milković
}

Original scientific paper Objective parameters of the room acoustics quality are obtained from the impulse response, which is measured using the appropriate PC based acoustic measurement system with two types of loudspeakers. Such measurement gives the impulse response that is the result of measurement of the entire system, which consists of the room and electro acoustics equipment. In order to investigate the real influence of loudspeakers on the measurement results, the research was made in the same measuring conditions. Impulse responses were measured with the same measuring system. Measuring point was selected at the optimum listening position in the room, and all measurements were carried out in the same place. The loudspeakers were placed at the optimum and characteristic positions in the room, and rotated around their axes in order to determine the impact of their position and directivity characteristics on the measurement of objective parameters of room acoustic quality.

Keywords: acoustic measurements; impulse response; objective acoustics quality; room acoustics; sound source

\section{Utjecaj izvora zvuka na rezultate mjerenja objektivnih parametara akustičke kvalitete prostora}

Izvorni znanstveni članak Vrijednosti objektivnih parametara akustičke kvalitete prostora dobivaju se iz impulsnog odziva, koji se mjeri odgovarajućom opremom temeljenom na osobnom računalu, s dvije vrste zvučnika. Takvo mjerenje daje impulsni odziv koji je rezultat mjerenja cijelog sustava, koji se sastoji od prostora 1 primijenjene elektoakustičke opreme. Napravljeno je istraživanje koliki je stvarni utjecaj zvučnika na rezultate mjerenja. Impulsni odzivi mjereni su uvijek istom opremom, a mjerne točke su odabrane tako da budu na optimalnom mjestu za slušanje, i sva mjerenja su izvedena u istom prostoru. Zvučnici su smješteni na optimalnim i karakterističnim mjestima u prostoriji, i rotirani su oko vertikalne osi u cilju utvrđivanja utjecaja njihove pozicije i usmjerne karatkeristike na rezultate mjerenja objektivnih parametara akustičke kvalitete prostora.

Ključne riječi: akustička mjerenja; akustika prostora; impulsni odziv; izvor zvuka; objektivna akustička kvaliteta

\section{Introduction}

The objective parameters of room acoustic quality are usually, according to recommendations, measured with an omnidirectional sound source. However, the quality of professional control and listening rooms is not affected only by the objective parameters of acoustic quality, but also by applied electroacoustical system, which certainly directly affects the value of objective parameters. According to this, measurement of objective parameters of room acoustic quality was made with two types of sound sources placed at several different places in the room, where at each of these places sound sources were rotated about their vertical axes through $360^{\circ}$, with increments of $45^{\circ}$. Measuring point was fixed, except that in one case a measurement microphone was used, and in other the artificial head and torso simulator. At the end, a special case was observed, when the room was excited with two identical sound sources, driven in the same time.

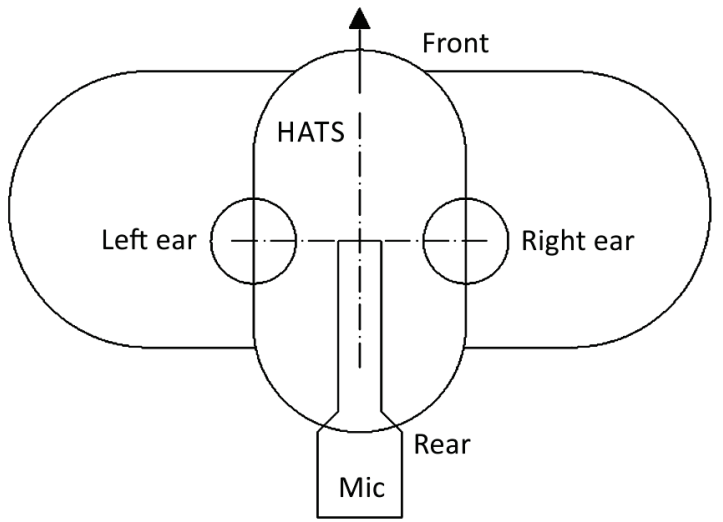

Figure 1Position of measuring microphone and HATS at Measuring point MP

\section{Measurement settings \\ 2.1 Sound receivers}

Measuring Point MP was always in the same location, height $1,10 \mathrm{~m}$ above the floor (distance from the floor of the human ear for seated listeners). In the first case the measurement was made with a measuring microphone, and in the second with a head and torso simulator (HATS), where the microphone was placed in the median plane of the artificial head and at artificial ear height, Fig. 1.

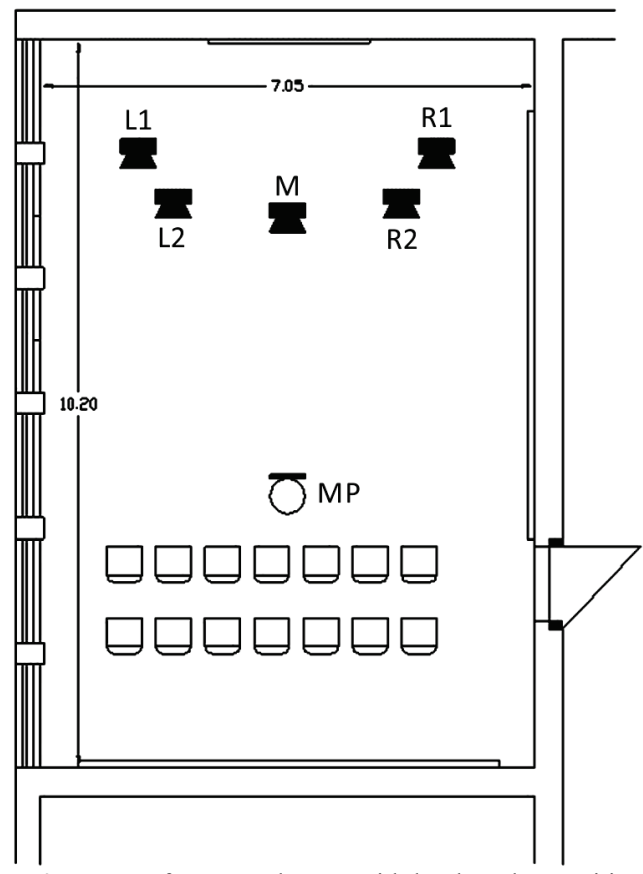

Figure 2 Layout of measured room with loudspeaker positions and measuring point 


\subsection{Sound sources}

Two different types of loudspeakers were used as sound sources. Their positions are shown in Fig. 2. In positions R1 and L1 one (same) sound source is used, while in positions $\mathrm{M}$ and R2 and L2 second sound source was used. Both were placed on the stand, first at the height of 1,35 $\mathrm{m}$ from the floor and the other at a height of $1,65 \mathrm{~m}$ from the floor. The sound sources placed in positions L1, R1 and $\mathrm{M}$ were rotated counterclockwise, with step of $45^{\circ}$, see Fig. 3. The last measurement was specifically made to study the effects of two identical sound sources driven simultaneously, placed in positions R2 and L2. They were rotated, too, the right sound source R2 was rotated counterclockwise and the left sound source L2 was rotated in a clockwise direction, both with step of $45^{\circ}$, see Fig. 4.

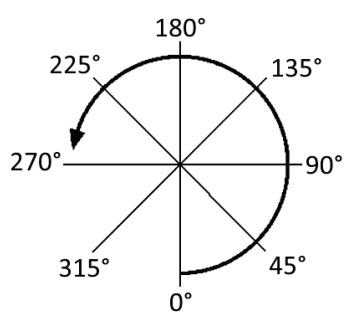

Figure 3 Rotation of loudspeakers R1, L1 and M with step of $45^{\circ}$
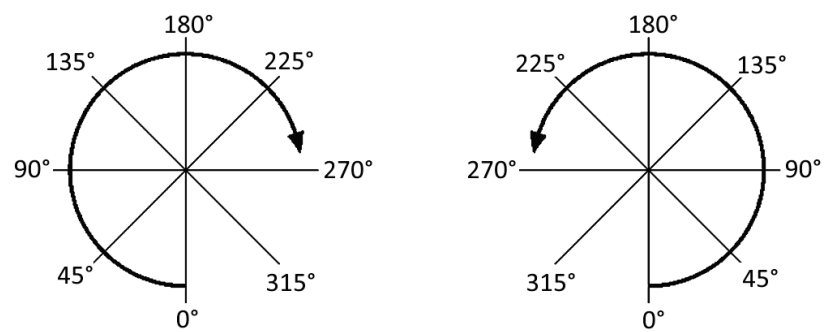

Figure 4 Rotation of loudspeakers R2 and L2 when driven together with step of $45^{\circ}$

\subsection{Measuring method}

Measuring was based on PC measuring system, with the measuring system layout shown in Fig. 5.

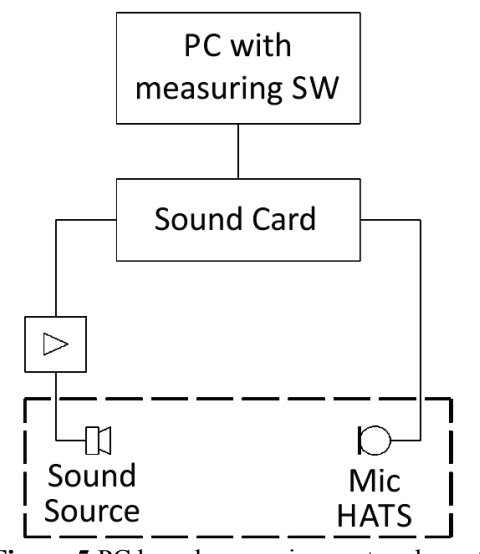

To measure the value of objective parameters of acoustic quality at each position in the room and for each angular position, measurements of the impulse response were made first. For that purpose, three different exciting signals with the following characteristics were used:

- Signal Type:

- Sweep, linear, weighting: white

- Sweep, logarithm, weighting: pink

- MLS, weighting: white

- Signal length: 5,5 s

- $\quad$ Sampling frequency $f_{\mathrm{s}}=48 \mathrm{kHz}$

- Number of presends: 1

- Averages: 5

Based on the measured impulse response, the following objective parameters of room acoustic quality were obtained: Reverberation time EDT, $\mathrm{T}_{10}, \mathrm{~T}_{20}$ and $\mathrm{T}_{30}$ (1/1 Oct); $\mathrm{C}_{7}, \mathrm{C}_{50}$ and $\mathrm{C}_{80}$ (1/1 Oct); D (1/1 Oct); MTI; STI; $\mathrm{Al}_{\text {cons; }}$; STI (Male); STI (Female); RaSTI; EquivSTIPa (Male); EquivSTIPa (Female).

\section{Measurement results}

For the purpose of this research, all together approx. 200 measurements were made, and the obtained results and differences between those results were observed.

Since there is a really big amount of data to be shown, in this article only the analysis which was made with reverberation time EDT, $\mathrm{T}_{10}, \mathrm{~T}_{20}, \mathrm{~T}_{30}$ is shown. The reverberation time is defined as the time needed to sound pressure level in the room drops by $60 \mathrm{~dB}$ after the termination of sound source reproduction.

Since it is often difficult to achieve the dynamic of 60 $\mathrm{dB}$ in the room for measurement purposes, reverberation time is estimated based on measured values of sound pressure falls to 10,20 or $30 \mathrm{~dB}$, where in the ISO3382 it is defined:

- $\mathrm{RT}_{30}$ - time required to sound pressure drops from the value of $-5 \mathrm{~dB}$ to $-35 \mathrm{~dB}$ extrapolated to a decrease of $60 \mathrm{~dB}$

- $\mathrm{RT}_{20}$ - time required to sound pressure drops from the value of $-5 \mathrm{~dB}$ to $-25 \mathrm{~dB}$ extrapolated to a decrease of $60 \mathrm{~dB}$

- $\mathrm{RT}_{10}$ - time required to sound pressure drops from the value of $-5 \mathrm{~dB}$ to $-15 \mathrm{~dB}$ extrapolated to a decrease of $60 \mathrm{~dB}$

- $\quad$ EDT - time required to sound pressure drops from the value of $0 \mathrm{~dB}$ to $-30 \mathrm{~dB}$ extrapolated to a decrease of $60 \mathrm{~dB}$.

The referent measurement was made with one loudspeaker, in position $\mathrm{R} 1$, angle $0^{\circ}$, with measuring microphone and HATS. The results of measurements including EDT, $\mathrm{T}_{10}, \mathrm{~T}_{20}, \mathrm{~T}_{30}$, STI and IACC are shown in Tab. 1, Tab. 2 and Tab. 3.

Table 1 EDT, $\mathrm{T}_{10}, \mathrm{~T}_{20}$ and $\mathrm{T}_{30}$ for $1 / 1$ octave width, R1 / angle $0^{\circ}$

\begin{tabular}{|c|c|c|c|c|c|}
\hline $\mathrm{Hz}$ & & $\mathrm{EDT}$ & $\mathrm{T}_{10}$ & $\mathrm{~T}_{20}$ & $\mathrm{~T}_{30}$ \\
\hline 125 & $\mathrm{~s}$ & 0,58 & 0,66 & 0,65 & 0,66 \\
\hline 250 & $\mathrm{~s}$ & 0,48 & 0,52 & 0,49 & 0,52 \\
\hline 500 & $\mathrm{~s}$ & 0,53 & 0,41 & 0,47 & 0,47 \\
\hline 1000 & $\mathrm{~s}$ & 0,47 & 0,52 & 0,44 & 0,46 \\
\hline 2000 & $\mathrm{~s}$ & 0,43 & 0,48 & 0,50 & 0,49 \\
\hline 4000 & $\mathrm{~s}$ & 0,42 & 0,49 & 0,52 & 0,50 \\
\hline 8000 & $\mathrm{~s}$ & 0,35 & 0,42 & 0,42 & 0,44 \\
\hline $250 \div 2000$ & $\mathrm{~s}$ & 0,48 & 0,48 & 0,48 & 0,49 \\
\hline $500 \div 4000$ & $\mathrm{~s}$ & 0,46 & 0,47 & 0,48 & 0,48 \\
\hline
\end{tabular}


Table 2 Speech intelligibility parameters, $\mathrm{R} 1 /$ angle $0^{\circ}$

\begin{tabular}{|l|c|}
\hline STI & 0,77 \\
\hline AlCons / \% & 2,63 \\
\hline STI (Male) & 0,77 \\
\hline STI (Female) & 0,78 \\
\hline RaSTI & 0,75 \\
\hline Equiv. STIPa (Male) & 0,79 \\
\hline Equiv. STIPa (Female) & 0,80 \\
\hline
\end{tabular}

Table 3 IACC values, R1 / angle $0^{\circ}$

\begin{tabular}{|c|c|c|c|}
\hline $\mathrm{Hz}$ & IACC $_{\text {Early }}$ & IACC $_{\text {Late }}$ & IACC $_{\text {Full }}$ \\
\hline 125 & 0,944 & 0,947 & 0,944 \\
\hline 250 & 0,803 & 0,618 & 0,761 \\
\hline 500 & 0,371 & 0,390 & 0,360 \\
\hline 1000 & 0,526 & 0,249 & 0,480 \\
\hline 2000 & 0,580 & 0,229 & 0,542 \\
\hline 4000 & 0,550 & 0,280 & 0,520 \\
\hline 8000 & 0,237 & 0,164 & 0,225 \\
\hline
\end{tabular}

First, the influence of sound source rotation is examined, and the results are shown on Figs. 6, 7 and 8.

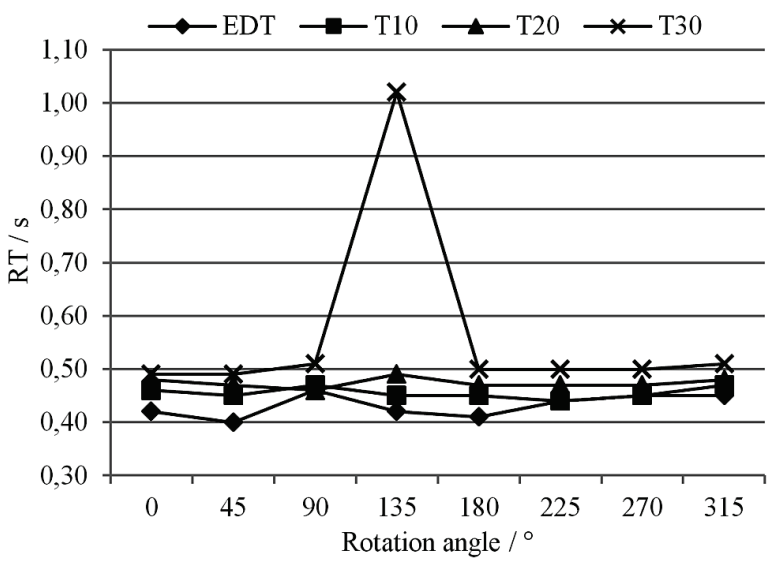

Figure 6 Values of reverberation time depending on the rotation angle for position R1, measured with exciting signal: linear sweep, weighting white

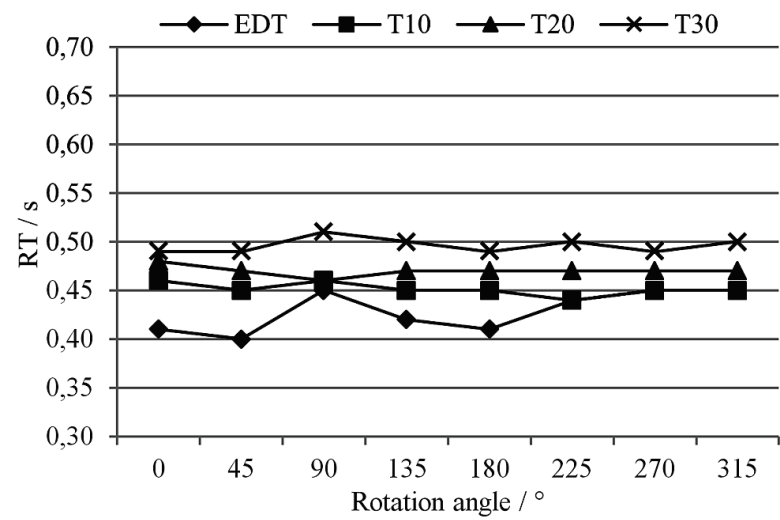

Figure 7 Values of reverberation time depending on the rotation angle for position R1, measured with exciting signal: linear log, weighting pink

Since the difference between EDT, $\mathrm{T}_{10}, \mathrm{~T}_{20}$ and $\mathrm{T}_{30}$ is minimal for linear log exciting signal, with weighting pink, regardless of rotation angle, the influence of sound source position in the room is shown only for this signal, Figs. 9 and 10.

At the end, one special and not usual way of measuring is used, where the exciting signal was emitted in the same tame (speaker bridge mode) through two identical speakers, on position R2 and L2, Fig. 11.

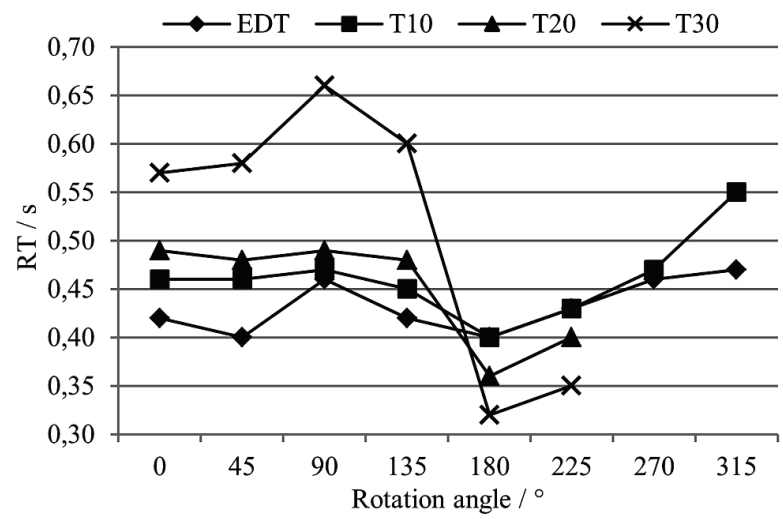

Figure 8 Values of reverberation time depending on the rotation angle for position R1, measured with exciting signal: MLS

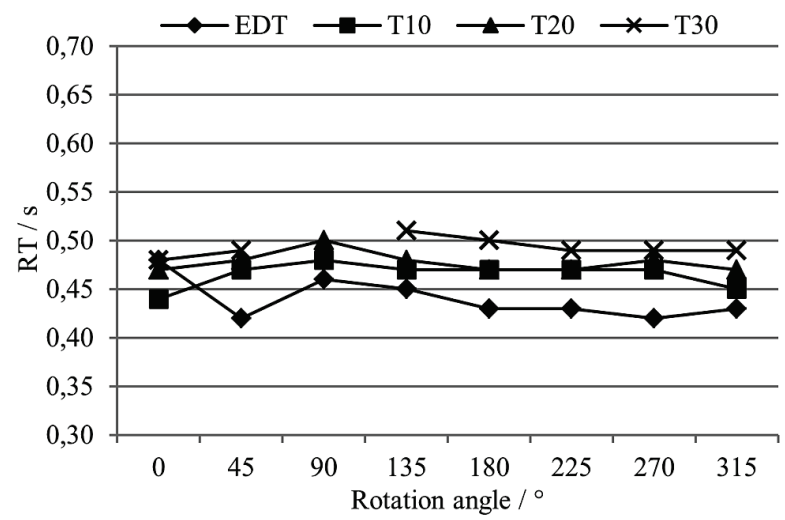

Figure 9 Values of reverberation time depending on the rotation angle for position L1, measured with exciting signal: linear log, weighting pink

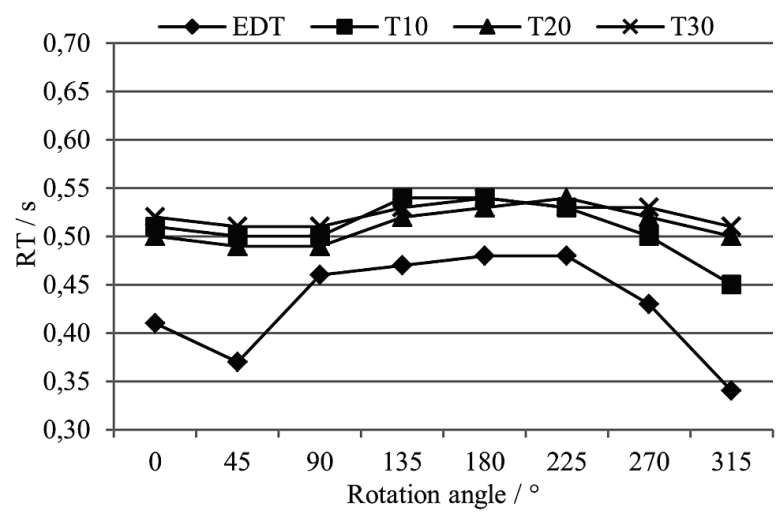

Figure 10Values of reverberation time depending on the rotation angle for position M, measured with exciting signal: linear log, weighting pink

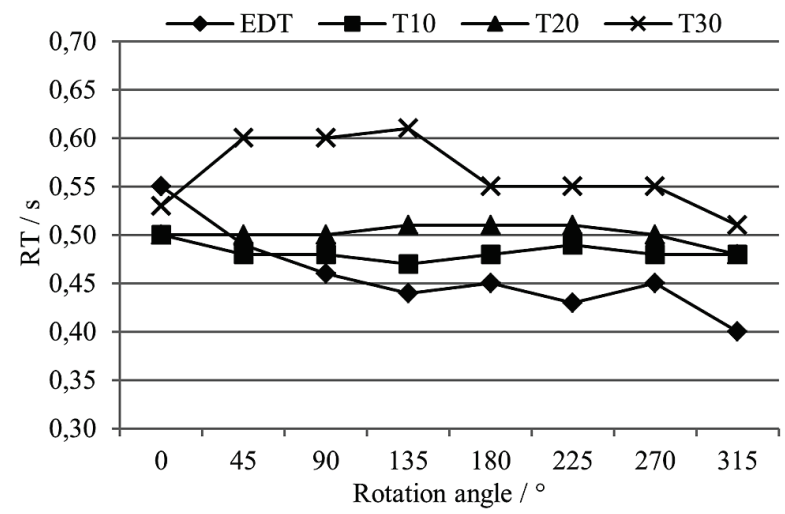

Figure 11 Values of reverberation time depending on the rotation angle for position $\mathrm{R} 2+\mathrm{L} 2$, measured with exciting signal: linear log, weighting pink 


\section{The statistical analysis of the measurements results}

One approach to data analysis is the application of statistical methods of analysis in order to determine the relevance of the data obtained and the resulting discrepancies. Statistical analysis of the effect of the signal influence on the results, a statistical analysis of the position of the sound source in the room, as well as statistical analysis of the effect of rotation on the sound source obtained measurement results was made. The results are shown in Figs. 12, 13, 14 and 15.

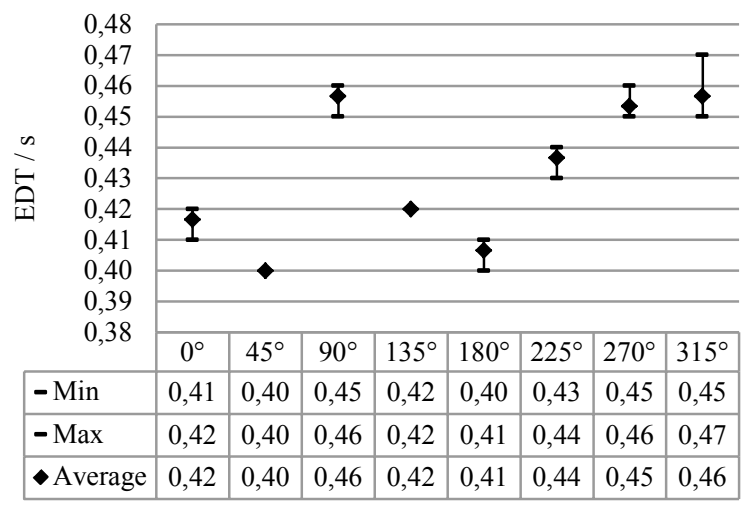

Figure 12 Reverberation time EDT - Minimum, maximum and average value depending on excitation signal and rotation angle, position R1

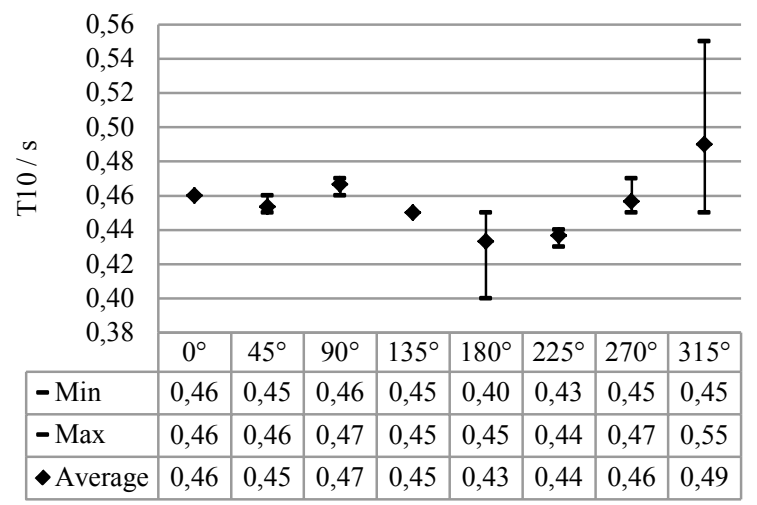

Figure 13 Reverberation time $\mathrm{T}_{10}$ - Minimum, maximum and average value depending on excitation signal and rotation angle, position R1

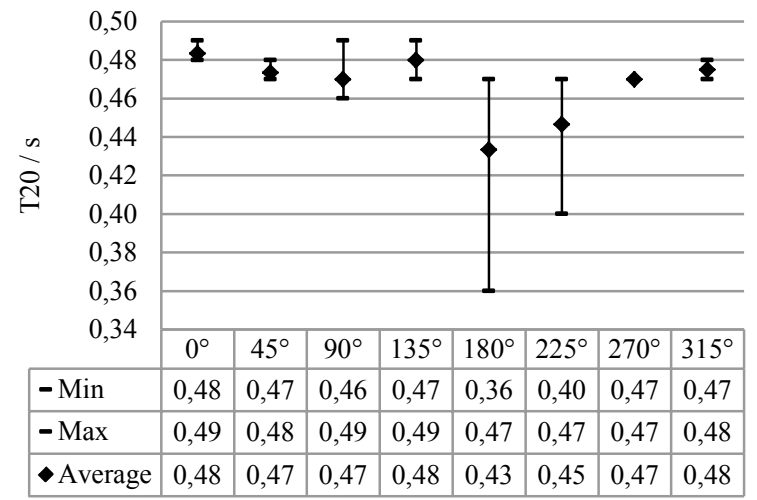

Figure 14 Reverberation time $\mathrm{T}_{20}$ - Minimum, maximum and average value depending on excitation signal and rotation angle, position R1

It should be noted that the standard deviation is at least dependent on the excitation signal with the results of EDT, with as many as two rotation angles of $45^{\circ}$ and $135^{\circ}$ where results are independent of the excitation signal (angles symmetric around the center line of the space).

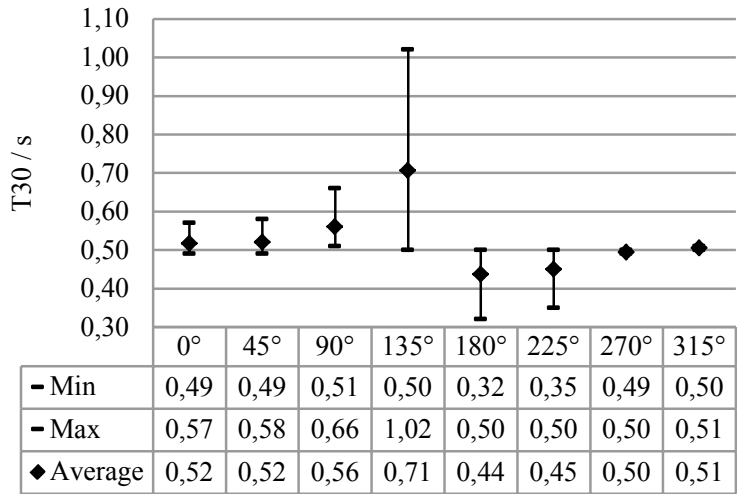

Figure 15 Reverberation time $\mathrm{T}_{30}$ - Minimum, maximum and average value depending on excitation signal and rotation angle, position R1

The biggest difference is for the parameter $T_{30}$, since there is a need for the maximum signal dynamics, where again there is certain symmetry with respect to the rotation angle, Tab. 4.

Table 4 Standard deviation depending on rotation angle

\begin{tabular}{|c|c|c|c|c|}
\hline $\begin{array}{c}\text { Rotation } \\
\text { angle } /{ }^{\circ}\end{array}$ & $\sigma(\mathrm{EDT})$ & $\sigma\left(\mathrm{T}_{10}\right)$ & $\sigma\left(\mathrm{T}_{20}\right)$ & $\sigma\left(\mathrm{T}_{30}\right)$ \\
\hline 0 & 0,0047 & 0,0000 & 0,0047 & 0,0377 \\
\hline 45 & 0,0000 & 0,0047 & 0,0047 & 0,0424 \\
\hline 90 & 0,0047 & 0,0047 & 0,0141 & 0,0707 \\
\hline 135 & 0,0000 & 0,0000 & 0,0082 & 0,2253 \\
\hline 180 & 0,0047 & 0,0236 & 0,0519 & 0,0826 \\
\hline 225 & 0,0047 & 0,0047 & 0,0330 & 0,0707 \\
\hline 270 & 0,0047 & 0,0094 & 0,0000 & 0,0050 \\
\hline 315 & 0,0094 & 0,0432 & 0,0050 & 0,0050 \\
\hline
\end{tabular}

Statistical analysis of the results depending on the rotation angle is given in Figs. 16, 17, 18 and Tab. 5 wherein the measurements are made with the excitation by the loudspeaker in position $\mathrm{R} 1$, while the excitation signal was changed accordingly.

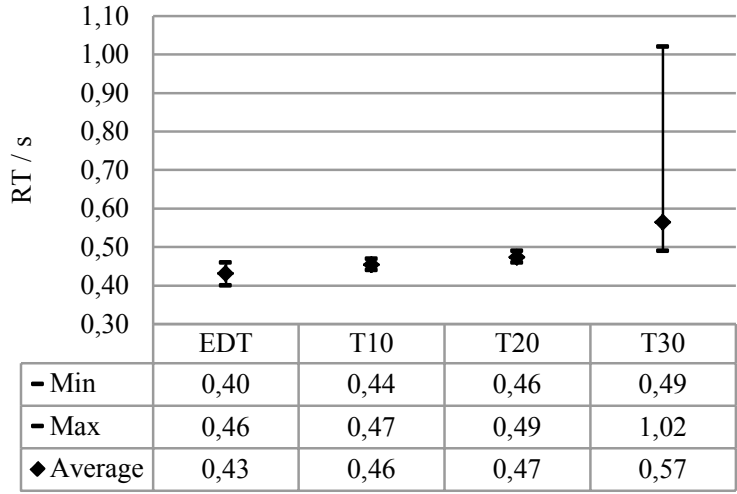

Figure 16 Minimum, maximum and average value of RT depending on rotation angle in position $\mathrm{R} 1$, with linear sweep, weighting white excitation signal

Table 5 Standard deviation depending on excitation signal

\begin{tabular}{|c|c|c|c|c|}
\hline & $\sigma(\mathrm{EDT})$ & $\sigma\left(\mathrm{T}_{10}\right)$ & $\sigma\left(\mathrm{T}_{20}\right)$ & $\sigma\left(\mathrm{T}_{30}\right)$ \\
\hline SW lin W & 0,0203 & 0,0100 & 0,0086 & 0,1721 \\
\hline SW log P & 0,0196 & 0,0060 & 0,0050 & 0,0070 \\
\hline MLS & 0,0259 & 0,0401 & 0,0510 & 0,1296 \\
\hline
\end{tabular}




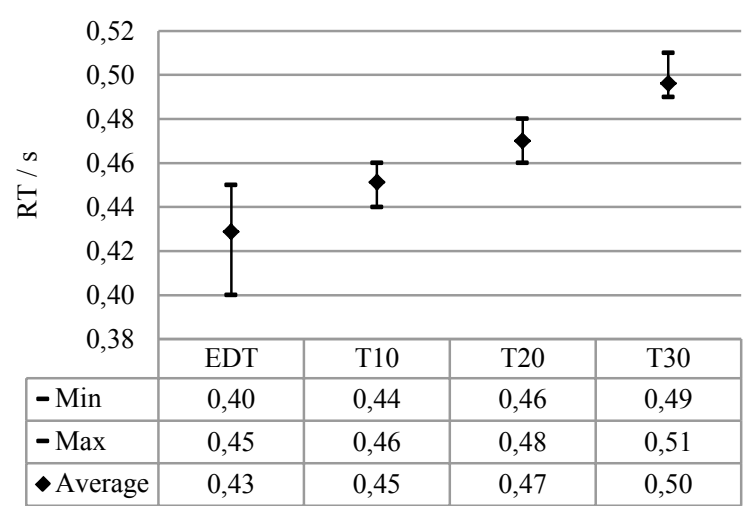

Figure 17 Minimum, maximum and average value of RT depending on rotation angle in position $\mathrm{R} 1$, with logarithm sweep, weighting pink, excitation signal

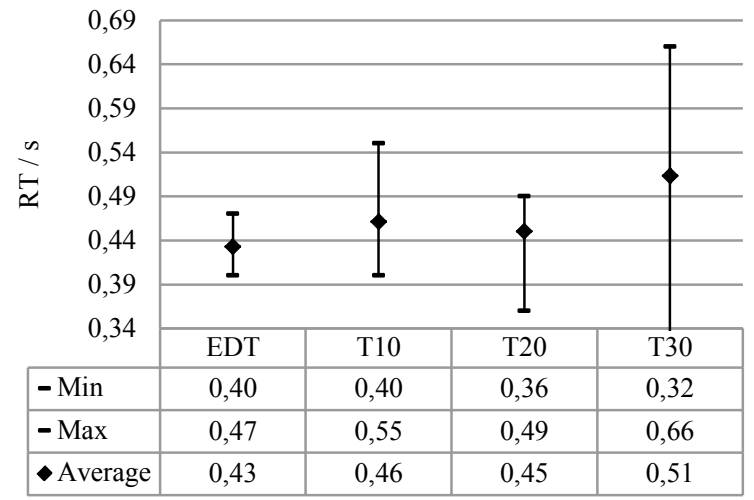

Figure 18 Minimum, maximum and average value of RT depending on rotation angle in position R1, with MLS excitation signal

The results also depend on the position of the loudspeaker in the room, while the excitation signal was always the same - logarithm sweep with weighting pink. Results are shown in Figs. 19 and 20 and Tab. 6.

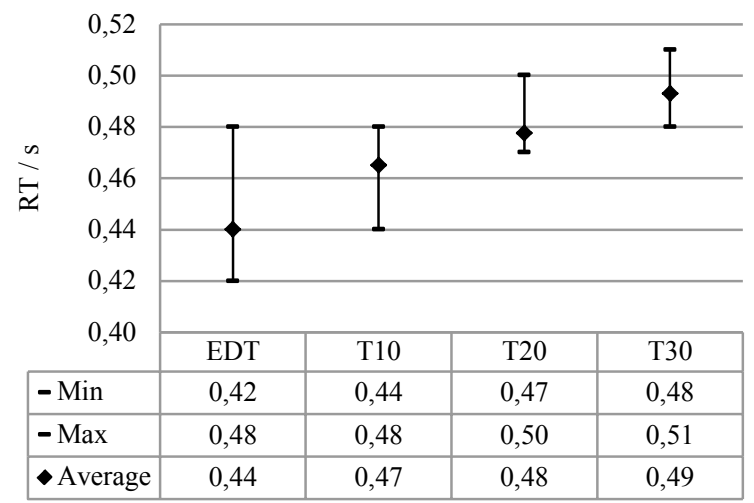

Figure 19 Minimum, maximum and average value of RT depending on rotation angle in position L1, with logarithm sweep, weighting pink, excitation signal

Table 6 Standard deviation depending on position

Table 6 Standard deviation depending on position
\begin{tabular}{|c|c|c|c|c|}
\hline & $\sigma(\mathrm{EDT})$ & $\sigma\left(\mathrm{T}_{10}\right)$ & $\sigma\left(\mathrm{T}_{20}\right)$ & $\sigma\left(\mathrm{T}_{30}\right)$ \\
\hline L1 & 0,0200 & 0,0122 & 0,0097 & 0,0088 \\
\hline M1 & 0,0495 & 0,0276 & 0,0176 & 0,0109 \\
\hline R2+L2 & 0,0420 & 0,0083 & 0,0093 & 0,0342 \\
\hline
\end{tabular}

Looking at all the obtained results so far, it is clear and confirmed that the results of measurements depend on the parameters of measurement, measuring equipment, and the way how the same measuring equipment is used, as well as on the measuring signal. The question is how these differences are really important and statistically significant. What is the real significance of the statistical dependence of the measuring results of the room acoustic quality parameters depending on, for example, rotation of the speaker which is used for excitation of the room. Looking, on the other hand, how important it is where to place the measuring equipment in the room during the measurement, at what distance it will be apart from each other sound source and receiver, under what mutual angle, and under what angle according to the centerline of the room, Fig. 21

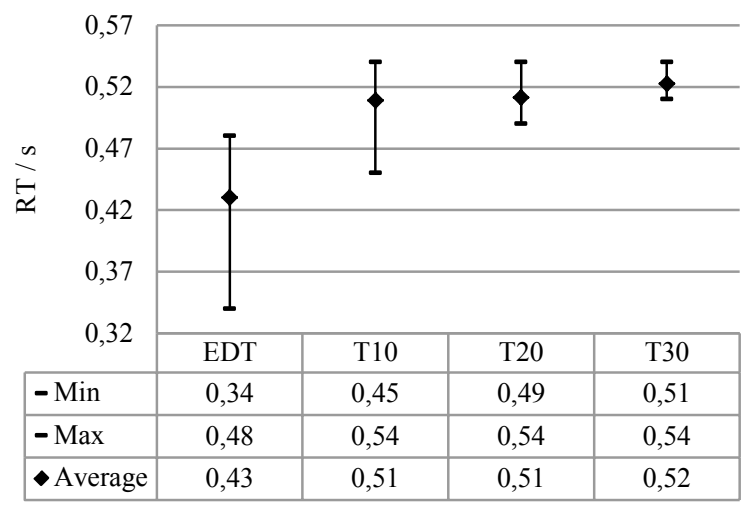

Figure 20 Minimum, maximum and average value of RT depending on rotation angle in position M1, with logarithm sweep, weighting pink, excitation signal

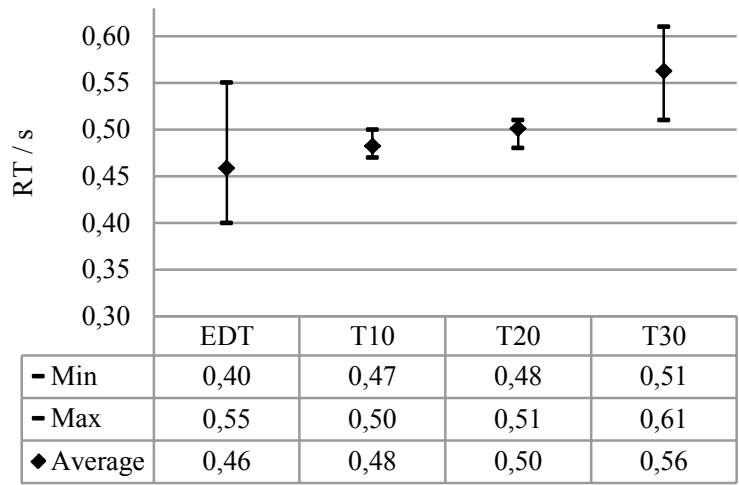

Figure 21Minimum, maximum and average value of RT depending on rotation angle in positions $\mathrm{R} 2+\mathrm{L} 2$, with logarithm sweep, weighting pink, excitation signal

In order to determine the impact of loudspeakers characteristics and the rotation of loudspeakers on the results of room acoustics parameters measurements, the hypothesis $\mathrm{H}$ was defined. In its definition so far obtained results were also taken into account.

Hypothesis H: The measured results depend on the rotation of the sound source.

For this purpose, we use the random variable $T$, which has a symmetric Student distribution with $n-1$ degrees of freedom.

$$
T=\frac{\bar{X}-a}{\frac{S}{\sqrt{n}}},
$$


where is:

$\bar{X}$-Average value

$a$-Hypothesis value

$S$-Standard deviation

$n$-Number of degrees of freedom.

We chose reliability levels $\alpha=0,01, \alpha=0,05$ and $\alpha=0,01$, and from the Student distribution table the value of the quantile for 7 degrees of freedom was read, and this is:

$$
\begin{aligned}
& \chi_{0,10}=-\chi_{0,90}=1,895, \\
& \chi_{0,05}=-\chi_{0,95}=2,365, \\
& \chi_{0,01}=-\chi_{0,99}=3,499 .
\end{aligned}
$$

That means that for such a defined random variable $\mathrm{T}$ the truth is:

$$
\begin{aligned}
& P(T>1,895)=0,90, \\
& P(T>2,365)=0,95, \\
& P(T>3,499)=0,99 .
\end{aligned}
$$

The results of logical tests for hypothesis $\mathrm{H}$ with defined significance are shown in Tabs. $7 \div 12$ below, where $\mathrm{T}$ means that hypothesis $\mathrm{H}$ is "True", and $\mathrm{F}$ means that $\mathrm{H}$ is "False".

Table 7 Hypothesis test in position R1 with excitation signal linear sweep, weighting white

\begin{tabular}{|c|c|c|c|}
\multicolumn{4}{|c}{ sweep, weighting white } \\
\hline EDT & $\alpha=0,01$ & $\alpha=0,05$ & $\alpha=0,01$ \\
\hline $\mathrm{T}_{10}$ & $\mathrm{~T}$ & $\mathrm{~T}$ & $\mathrm{~T}$ \\
\hline $\mathrm{T}_{20}$ & $\mathrm{~T}$ & $\mathrm{~T}$ & $\mathrm{~T}$ \\
\hline $\mathrm{T}_{30}$ & $\mathrm{~F}$ & $\mathrm{~T}$ & $\mathrm{~T}$ \\
\hline
\end{tabular}

Table 8 Hypothesis test in position R1 with excitation signal logarithm sweep, weighting pink

\begin{tabular}{|c|c|c|c|}
\hline & $\alpha=0,01$ & $\alpha=0,05$ & $\alpha=0,01$ \\
\hline EDT & $\mathrm{F}$ & $\mathrm{F}$ & $\mathrm{T}$ \\
\hline $\mathrm{T}_{10}$ & $\mathrm{~F}$ & $\mathrm{~F}$ & $\mathrm{~F}$ \\
\hline $\mathrm{T}_{20}$ & $\mathrm{~F}$ & $\mathrm{~F}$ & $\mathrm{~F}$ \\
\hline $\mathrm{T}_{30}$ & $\mathrm{~F}$ & $\mathrm{~F}$ & $\mathrm{~T}$ \\
\hline
\end{tabular}

Table 9 Hypothesis test in position R1 with excitation signal MLS

\begin{tabular}{|c|c|c|c|}
\hline & $\alpha=0,01$ & $\alpha=0,05$ & $\alpha=0,01$ \\
\hline EDT & $\mathrm{T}$ & $\mathrm{T}$ & $\mathrm{T}$ \\
\hline $\mathrm{T}_{10}$ & $\mathrm{~T}$ & $\mathrm{~T}$ & $\mathrm{~T}$ \\
\hline $\mathrm{T}_{20}$ & $\mathrm{~F}$ & $\mathrm{~T}$ & $\mathrm{~T}$ \\
\hline $\mathrm{T}_{30}$ & $\mathrm{~T}$ & $\mathrm{~T}$ & $\mathrm{~T}$ \\
\hline
\end{tabular}

Table 10 Hypothesis test in position L1 with excitation signal logarithm sweep, weighting pink

\begin{tabular}{|c|c|c|c|}
\hline & $\alpha=0,01$ & $\alpha=0,05$ & $\alpha=0,01$ \\
\hline EDT & $\mathrm{F}$ & $\mathrm{F}$ & $\mathrm{F}$ \\
\hline $\mathrm{T}_{10}$ & $\mathrm{~F}$ & $\mathrm{~F}$ & $\mathrm{~F}$ \\
\hline $\mathrm{T}_{20}$ & $\mathrm{~F}$ & $\mathrm{~T}$ & $\mathrm{~T}$ \\
\hline $\mathrm{T}_{30}$ & $\mathrm{~F}$ & $\mathrm{~F}$ & $\mathrm{~F}$ \\
\hline
\end{tabular}

Table 11Hypothesis test in position M1 with excitation signal logarithm sweep, weighting pink

\begin{tabular}{|c|c|c|c|}
\hline & $\alpha=0,01$ & $\alpha=0,05$ & $\alpha=0,01$ \\
\hline EDT & $\mathrm{T}$ & $\mathrm{T}$ & $\mathrm{T}$ \\
\hline $\mathrm{T}_{10}$ & $\mathrm{~T}$ & $\mathrm{~T}$ & $\mathrm{~T}$ \\
\hline $\mathrm{T}_{20}$ & $\mathrm{~T}$ & $\mathrm{~T}$ & $\mathrm{~T}$ \\
\hline $\mathrm{T}_{30}$ & $\mathrm{~T}$ & $\mathrm{~T}$ & $\mathrm{~T}$ \\
\hline
\end{tabular}

Table 12 Hypothesis test in position R2+L2 with excitation signal logarithm sweep, weighting pink

\begin{tabular}{|c|c|c|c|}
\hline & $\alpha=0,01$ & $\alpha=0,05$ & $\alpha=0,01$ \\
\hline EDT & $\mathrm{F}$ & $\mathrm{F}$ & $\mathrm{F}$ \\
\hline $\mathrm{T}_{10}$ & $\mathrm{~F}$ & $\mathrm{~F}$ & $\mathrm{~F}$ \\
\hline $\mathrm{T}_{20}$ & $\mathrm{~T}$ & $\mathrm{~T}$ & $\mathrm{~T}$ \\
\hline $\mathrm{T}_{30}$ & $\mathrm{~F}$ & $\mathrm{~F}$ & $\mathrm{~F}$ \\
\hline
\end{tabular}

From the results of testing the statistical significance of dependence of the results of measurements on sound source rotation, it is clear that the results at least depend on the rotation in the case of excitation with a logarithm sweep signal with weighting pink, as well as in the case when the sound source is placed in the middle of the room.

This is easy to understand, in the first case the energy of the signal is the biggest, and in the second, the influence of near reflection is not so strong.

\section{Conclusions}

After a detailed research process of all measuring results, of which only one little part is shown here, it is obvious that the results depend on excitation signal, and according to the achieved results, the best signal for use is logarithmic sweep signal, with pink weighting function.

The position of sound source in the room is also of influence, but not as big as rotation of the source, which means that directivity pattern also has to be taken into account while measuring and analyzing the results. In this article this is shown in the results for reverberation time values of EDT, $\mathrm{T}_{10}, \mathrm{~T}_{20}$ and $\mathrm{T}_{30}$.

If we apply this situation to the measurement of control rooms, for example, where the good listening conditions are the most important, the best way is to use already built-in equipment, through which the usual production processes are made. But, in this process all sound processors should be out of use, and the best way should be to connect measuring equipment directly to the input of loudspeaker, if we are talking about active loudspeakers, or directly to the power amplifier input, if there is PA. In this way we will obtain the real results, which we can use in all further research, and correlation with subjective parameters of acoustic quality. At the end, the subjective assessment is the most important, because it is always the most important thing how we can hear what we are listening to.

The control measurements have to be made with another, well known unidirectional sound source. This is the next step in this investigation process, when we are going to compare the results obtained with built in speakers and with omnidirectional sound source.

At the end, the really relevant results can be obtained only based on all those results analyzed together, and the good correlation between results of objective acoustics parameters measurements and subjective assessments must be obtained.

The presented results also indicate the need for taking into account the interaction between acoustic and electroacoustic parameters for measuring and evaluation of acoustic quality of the room where electroacoustic sound system is applied. 


\section{References}

[1] Fajt, S.; Krhen, M.; Jambrošić, K. Subjective evaluation of room acoustic quality - statistical analysis, Proceedings of $1^{\text {st }}$ EAA - Euroregio 2010, Ljubljana, Slovenia, 2010.

[2] Fajt, S.; Krhen, M.; Vodopija, J. Lecture and Multimedia rooms - Measurements and acoustical design, Proceedings of $2^{\text {nd }}$ UNTREF International Congress on Acoustics, Buenos Aires, Argentina, 2010.

[3] Domitrović, H.; Fajt, S.; Krhen, M. Multimedia Room Acoustical Design, Proceedings ELMAR, Zadar, 2009.

[4] Domitrović, H.; Krhen, M.; Miličević, D. Sound in Multimedia Systems, Proceedings ELMAR, Zadar, 2009.

[5] Krhen, M. Ocjena akustičke kvalitete prostora, Master Thesis, University of Zagreb, Faculty of Electrical Engineering and Computing, Zagreb, 1994.

[6] Fajt, S. Vrednovanje kvalitete akustički obrađenih prostora, PhD Thesis, University of Zagreb, Faculty of Electrical Engineering and Computing, Zagreb, 2000.

[7] Everest, F. A.; Pohlmann, K. C. Master Handbook of Acoustics, McGraw-Hill Companies, SAD, 2009.

\section{Authors' addresses}

SinišaFajt, Ph. D., Associate Professor

University of Zagreb, Faculty of Electrical Engineering and Computing, Department of Electroacoustics

Unska 3, HR-10000 Zagreb, Croatia

E-mail: sinisa.fajt@fer.hr

\section{Miljenko Krhen, Ph. D., Postdoctorand}

University of Zagreb, Faculty of Electrical Engineering and Computing, Department of Electroacoustics

Unska 3, HR-10000 Zagreb, Croatia

E-mail: miljenko.krhen@fer.hr

\section{Marin Milković, Ph.D., Professor}

University North

Trg dr. Žarka Dolinara 1, HR-48000 Koprivnica, Croatia

E-mail: marin.milkovic@unin.hr 